\title{
The Spirit of Canadian Democracy \\ Margaret Fairley and the Communist Cultural Worker's Responsibility to the People
}

\author{
David Kimmel
}

In 1972, Margaret Atwood wrote a book to guide thousands of previously ignorant Canadians who had suddenly shown a great interest in 'home-grown' literature. Public enthusiasm was so intense that well over 70000 copies of Survival have been sold (and it is still in print). Yet only four years after the book first appeared, Atwood said she felt her work interpreting and introducing 'CanLit' was done. Canadians, in large numbers, had finally discovered their cultural heritage. What caused this remarkable, sudden interest is still an open question. Centennial celebrations in 1967 certainly left Canadians with residual nationalistic sentiments. The Massey Commission of the 1950 s also left a legacy of cultural nationalism. And educational institutions had begun to put Canadian literature on the curriculum. Each one of these phenomena infused national arts and letters with financial support and other forms of encouragement as never before. Indisputably, the 1970s had been a turning point. But Atwood, when writing about previous generations, misrepresented historical fact by stating that "Canadian literature was not taught, required, or even mentioned (except with derision) in the public sphere." She knew little of the careful attention paid to Canada's literary history by Communist cultural workers since the 1930s. Had she known more about educators such as Margaret Fairley, she might have seen the teaching of Canadian culture in a slightly different light.

No highbrow royal commission or state-organized national anniversary gave rise to Fairley's educational work. Teaching the masses about their cultural heritage was part and parcel of a Marxist project. After all, people's labor had created the nation; their labor, therefore, was the basis of Canada's culture. Communist educators believed that teaching the masses was also instrumental in uncovering the spirit of democracy. To them, democracy meant the whole population knowing and sharing its heritage, drawing a sense of community and accomplishment from it, and knowing that everyone had - or could have - a hand in its consumption. Fairley's forty-year career as teacher, historian, editor, and journalist serves as one of the best examples of the work Canadian Communist cultural workers did. She fulfilled the cultural worker's responsibility to the people.

She was born Margaret Adele Keeling in Bradford, Yorkshire on 20 November 1885. Like many British-born socialists of her generation, she came from a well-todo, conservative family. Her father was an Anglican priest and headmaster of a prestigious grammar school. One of her brothers, Sir Edward Keeling, was a Tory member of parliament, mayor of Westminster, and author of the anti-Communist

I wish to thank Paul Axelrod, Gregory Kealey, Pasquale Turbide, and the editors of left history for their advice on improving this paper.

1 Margaret Atwood, Survival: A Thematic Guide to Canadian Literature (Toronto 1972), 11-19. Earl G. Ingersoll, Margaret Atwood: Conversations (Willowdale, Ontario 1990), xii; Mary Ell is Gibson, "Thinking About the Technique of Skiing When You're Halfway Down the Hill," in Ingersoll, 33. 
pamphlet In Russia Under the Bolsheviks. Margaret received her early education in Bradford and in 1904 entered St. Hilda's, one of the women's colleges at Oxford. Despite her brilliant performance in the study of history and English literature, she, like all Oxford women of her generation, was denied the degree she deserved. She wrote retrospectively of this experience "It is sometimes assumed that because Oxford does not give the degree to women, she treats them badly in other respects. I do not think this is the case." However, she also admitted that there were occasions when her "letterless condition" bothered her. ${ }^{2}$ She spent the year 1907-1908 as a teacher-in-training in London's impoverished East End. The appalling conditions of the working-class, in contrast with Oxford's cloisters and her own upbringing, opened Margaret's eyes to certain modern realities. Here she began to question the bourgeois values of her early life.

She returned to Oxford as a tutor in English only to leave what she called "that celibate life" in 1912. ${ }^{3}$ She traveled widely "to investigate the opportunities provided in Western Canada [as well as other places] for educational work for women" but without success. Ironically, it was back at Oxford that she met H.M. Tory, president of the University of Alberta. He offered to grant her Alberta's B.A. and to make her that university's first dean of women. Thus it was she went "from one of the oldest seats of learning...to one of the newest." In Edmonton she met Professor Barker Fairley who had just begun his brilliant career as a German literary scholar. They married in 1913 and soon after Margaret gave birth to the first of her five children. As was then the practice, she was made to resign her duties as dean. ${ }^{4} \mathrm{Her}$ marriage, family, and in 1915 the Fairleys' relocation to Toronto surely diverted her attention from teaching for several years. However, during this period, something apparently rekindled in her what would become a life-long sympathy for left-wing politics. Precisely what that something was - her dismissal from university duties, her day-to-day life as wife ånd mother, or some other factor - remains unclear.

Several years passed before she returned to public intellectual work. The bulk of her earliest writing was published in the pages of the left-liberal arts and current affairs journal Canadian Forum. ${ }^{5}$ Her first article concerned the plight of women in the modern world. It is a thoughtful piece, a consideration of what she called "the theory of self-effacement and self-sacrifice which generations ago men invented to keep women in their place...." Her ideas at this point were informed by a non-Marxian scheme of economics and sociology. Thoreau's philosophy of material consumption and work resonates in her words. She also invoked as examples the lives of Christ and St. Francis, as well as Quaker founder George Fox and Italian puritan Girolano

2 Early biographical details have been drawn largely from three sources: my interviews with several members of Fairley's family and circle of friends; John Greenlee's interview with Barker Fairley in 1979 (University of Toronto Archives, B87-0047/001); and Paul Duval's quasi-biography Barker Fairley (Toronto 1980). Several family members, including father William and brother Edward, are listed in various editions of Who Was Who. Fairley's Oxford experience is described in M.A. Keeling, "Women Students in Oxford," in The Gateway [University of Alberta] (October 1912), 49-51.

3 This phrase is taken from a brief biographical outline appended to the finding aid to the Margaret Fairley Manuscript Collection [hereafter cited as "Manuscript Collection"], Thomas Fisher Rare Book Library, University of Toronto.

4 University of Alberta Archives, 68-9-219, letter of introduction from Henry W. Crees to H.M. Tory (12 February 1912); "Miss M.A. Keeling," in The Gateway, (October 1912), 48.

5 Canadian Forum came into being in 1920 when Barker Fairley reorganized the University College student periodical The Rebel. Margaret penned several book reviews and commentaries for The Rebel. Her first published work, however, was a small edition of Coleridge's Rime of the Ancient Mariner produced by Clarendon Press in 1912. In the late 1920s, she joined the Forum's editorial board. 
Savonarola. But lurking in her argument was a more strident perspective. She called for women, especially educated ones, to "take a stand immediately, and so take possession of their own lives that they are no longer the victims of circumstance, but creators of a new way of life." In fact, she went so far as to advocate "some kind of domestic revolution." Women should

break through some of the dishes and do something drastic to win back our self-respect.... Only those housewives who value their time more than their jam can contribute much towards that new order where the life can be more than meat and the body more than raiment. ${ }^{6}$

Such a scheme was fine for informed middle-class women. Surely in her own liberal and studious household Fairley could practise what she preached. She would only later realize that many other women, members of the working class especially, did not have this privilege.

When she wrote again about women, after a hiatus of sixteen years, she did so with much more vigour. Through time and a series of important events, she gained a critical awareness of class distinctions, and of her own empowerment. Reviewing Honourable Estate, Vera Brittain's novel about the changed status of English women, Fairley remarked that only women of the privileged classes enjoyed positive changes. Concluding the article, she used Marxist language for the first time in her writing: "Those who enjoy Honourable Estate are, for the time at least, disqualified from any strenuous thinking. 'Heads up and eyes dry,"' Fairley wrote, "might be a good revolutionary slogan for the bourgeois left-minded minority to adopt."7 This Marxist perspective in her writing had emerged as the result of several encounters in Manchester, England. Her family had moved there in 1932, at the height of the Depression, when Barker was made head of the German department at the Victoria University. The poverty and other injustices of modern industrial England "deeply affected" Margaret, rekindling in her - permanently this time - a desire to struggle for democracy, peace, dignity, and other progressive causes. She wrote frequently, producing a series of articles on childhood in a journal called Family. And, under the probable tutelage of British intellectual Barbara Niven, Fairley joined the Communist Party of Great Britain. Her entry seems, to the historical eye at least, to have been rather abrupt. But her own account of the matter confirms that abrupt it was. She told Scottish Marxist poet and family friend Christopher Grieve (alias Hugh MacDiarmid) "It always surprises me to find that I learn in violent sudden jerks."

In 1936, the family moved yet once again, this time returning to Toronto. But this relocation did not interrupt her commitment to social and political pursuits. Soon after her arrival, she joined the Communist Party of Canada (CPC), "a decision that grew out of her increasingly deep feeling for Canada, [and] her intense enthusiasm for its future," as well as a continuing devotion to Marxist politics in general. As Barker Fairley told Grieve, upon their return to Canada, "Margaret [remained] very active in political discussion groups and in reviewing." And the journal she chose to contribute to reflected her new, more engaged philosophical view. New Frontier (not

Margaret Fairley, “Domestic Discontent," in Canadian Forum (November 1920), 45.

7 Margaret Fairley in New Frontier (February 1937), 29.

8 Duval, 97; letter from Barker Fairley to Grieve (4 March 1936) in the Hugh MacDiarmid Papers, Special Collections Department, Edinburgh University Library; Margaret Fairley to Grieve (24 June 1935), MacDiarmid Papers.

9 "Margaret Fairley, November 20, 1885 - February 14, 1968," Horizons (Spring 1968), 1-2; letters from Barker Fairley to Grieve, MacDiarmid Papers (4 March 1936 and 8 October 1937). 
to be confused with the later New Frontiers) was edited by Toronto social worker Margaret Gould, and made its first appearance in April 1936. The contents of the premier issue typified the journal's originally broad-based left-wing perspective. It included submissions from Graham Spry, C.B. Macpherson, Dorothy Livesay, and Stanley Ryerson. Gould's editorial article set forth New Frontier's aim: "to acquaint the Canadian public with the work of those writers and artists who are expressing a positive reaction to the social scene; and to serve as an open forum for all shades of progressive opinion." The latter objective, it seems, arose from the magazine's initial attempt to support a united socialist front. Choices such as these, it was believed, were the only way to stop the spread of fascism, while at the same time bringing about capitalism's collapse. These terms demonstrated the strength of the Marxism that influenced New Frontier's character and tone, even at its inception. For instance, the journal's editors considered art and writing in Canada to be "disregardful of or unfaithful to the social realities of our time." Although three reasons for these errors were given, the most cogent argument was the most Marxian, namely that Canadian culture suffered because, in Peter Stevens' words, its bourgeois creators "had tended to live in ivory towers." ${ }^{.10}$ Over time, New Frontier became more and more a strictly Communist organ, at one point defending the CPC after it had been criticized in Canadian Forum. Opinions expressed in a September 1936 article made clear how devoutly New Frontier had taken up the Communist line: "The future of humanity is Communism, the classless, stateless society, in which man will forever cease to use force against man, when exploitation will end and the real history of human development will at last begin." 11

It was in this milieu, therefore, that Fairley's work as a Communist thinker developed. Her thoughts easily fitted themselves into the nascent Canadian Marxist intellectual corpus. Previously, her Canadian Forum articles had exposed both her awareness of the consumerist tendencies of the capitalist system and her sensitivity to the ways in which popular education - a subject dear to her heart - detrimentally socialized young people. But her point-of-view, albeit revisionist, was, at that time, equivocal and hardly informed by Marxist thinking. Rather, this earlier perspective was founded on the more liberal ideas of intellectuals such as Shaw and Bergson. Her initial writing focused on the "overgrowth of custom and false and worldly doctrine" that was impeding reform. Presumably, such a view grew out of conflicts she had with her affluent Christian father. Recognizing and highlighting the liberating potential of breaking with custom (as she called it), she expressed the opinion that "If man is to rise above himself, the cramping influences of wealth as well as poverty, of arbitrary custom, and of the audacious tyranny of each generation upon the next must be removed." A cautionary tone prevailed in her early work. For example, she warned her readers to abandon the prevalent hero-worship culture she regarded as contrary to the democratic spirit of progress. Albeit far from revolutionary, implicit in such expression was an awareness of the need for change. Although her own convictions were still unformed and incomplete, notions of democracy and breaking with tradition stood her in good stead for the years ahead.

Fairley's contribution to New Frontier reveals the depth of her immersion into Marxism. She wrote the lead book review in the October 1937 issue, and in partisan

10 New Frontier, (April 1936), 1. See Peter Stevens, "The Development of Canadian Poetry Between the Wars and Its Reflection of Social Awareness," Ph.D. dissertation (University of Saskatchewan 1968), 237-244

11 E. Cecil Smith, "The Future of Humanity," in New Frontier (September 1936), 26. 
fashion, attacked the half-baked notions of reformist socialists, even the eminent Fabian political economist G.D.H. Cole, in this case. "It is no good," she wrote

for one heretical member of the Labor Party, even if he is a man of Cole's knowledge, to elaborate [a People's Front] program. It only confuses the issue of finding common ground with Liberals, orthodox Laborites and Communists. It is inappropriate to raise so many highly controversial subjects about which there is no prospect of agreement, after his clear and stirring appeal for unity or immediate action on the widest possible basis of opposition to war and fasism.

But her critical efforts did not stagnate in the remote context of the left's internal ideological squabbles. For instance, regarding the wider military and diplomatic realities of the 1930s, she admonished her readers to realize that "The battle is set; Europe is divided into two halves, fascist and anti-fascist, and it is time people's eyes were opened to the clear evidence of England's alliance." And they should be properly informed, not merely accepting the "snap-judgment journalist's account of world affairs." Fairley recognized how popular attitudes betrayed the ways in which the prevailing system took the conflict of classes for granted. "Our capitalist habits of thought," she wrote, "run in such deep ruts that it often takes a series of jolts and collisions to start our minds off on the new track." 12 As arduous as this task may have seemed, Fairley confronted it. Her adherence to Marxism gave her a focus, making the "jolts and collisions," in addition to the substance of her subsequent work, all the more persuasive.

Although a more clearly defined political philosophy strengthened the polemic of her writing, sadly, over time her Marxism and Communist Party membership had a somewhat deleterious effect on the attention she gave (in print) to women's issues. Little has been written about female political activists in the post-suffrage period. In one notable exception, Joan Sangster has investigated left-wing women, and even though her work concentrates on the contributions of these women to various social democratic causes, she is able to reach a general conclusion about Communists:

the political world view of most radical women, especially Communists, was shaped by theory, experiences of class and economic exploitation and by a re-education in socialist theory that rejected the "sexual antagonism" presumed to be characteristic of feminism.

In addition, as Meredith Tax remarks, what the CP called the "woman question" was commonly treated as a petty-bourgeois diversion from the class struggle. In Canada too, the CPC harboured a "strong antipathy to feminism." Largely for these reasons, Fairley hardly considered herself a feminist and wrote comparatively little in that vein. But she continued to be concerned with the female experience since, as her husband told Paul Duval, "she never isolated it from the [issue of the] rights of humanity in general."13

Fairley rarely missed, however, an opportunity to emphasize the role of progressive women in Canadian society. She often wrote about individuals like Nellie McClung, women who "have played their full part in the road to health, social

12 M.A.F[airley]. "A Socialist Urges Unity," review of The People's Front by G.D.H. Cole, New Frontier (October 1937), 24; Margaret Fairley, review of Behind the Spanish Barricades by John Langden-Davies, New Frontier (April 1937), 28; Margaret Fairley, review of Soviet Democracy by Pat Sloan, in New Frontier (July/August 1937), 30-31.

13 Joan Sangster, Dreams of Equality: Women on the Canadian Left, 1920-1950 (Toronto 1989), 8 and 88; Meredith Tax, "The Sound of One Hand Clapping: Women's Liberation and the Left," in Dissent (Fall 1988). 459; Duval, 14. 
security, racial tolerance and peace." The important theme in McClung's story was her realization as a child that she would have to choose between "ambition for a life of her own and the drudgery of endless chores." She also had to steer between what was expected of a woman and "what she knew women could and should be in the wider world." But she was not wholly exceptional; "Very many women of that time, and later, have gone through the same struggle." Fairley's message to her readers was that all women should be mindful of their progressive potential. Developing a wide-reaching public conscience was, in her mind, connected with women's struggle to take their fair share of responsibility in these matters. Informed Canadian women should, like pioneer McClung, arise and join the campaigns which lead directly to "a new world of peace and goodness." In addition, progressive men should realize that their cause would be strengthened if they abandoned what Meredith Tax calls the "pattern of male repression, exclusion, devaluation and just not getting the point."14

Such a 'pattern' had been prevalent in the CPC since the Third Period. However, by the early 1960 s, perhaps anticipating a return of women's rights activism and a new role for women in politics, the Party began to take Fairley's thoughts on gender issues more seriously. A "new world of peace and goodness," achieved through the active struggle of men and women for the ideals of equality and justice became more and more a part of the Communist platform. One very important example was the National Women's Committee which the CPC established with Fairley as mentor. Canada's Women, a booklet issued by the Committee and edited by Fairley, explained the Party's renovated views on women in society. Most of these views found their origins in the work Fairley had been doing for years. The booklet is a fine example of her "common touch" and its foreword typifies the extent to which she drew her own experiences into her philosophy and writing: "I happen to have seen with my own eyes evidence of the great changes which have transformed the lives of millions of women since I was a child." She was referring to the changes she had seen in industrial England since the end of the nineteenth century and the progress she perceived in Communist countries such as China and the Soviet Union. "In 1933," she wrote, "I saw the pale and thin children of Leningrad, after the terrible famine." Having returned there in 1959, she witnessed the advances that had been achieved through state economic planning. She also noted changes in Canada and the important fact that "women have taken a vital part in the struggles of workers and farmers." She gave as examples the fights for the franchise, unemployment insurance, and against conscription during the 1914-1918 war, as well as the organization of farmers in the inter-war period. "All these struggles and changes would have been slower and more painful if the women had not played their part." There were, however, on-going concerns confronting Canadians and the world, and she warned that progressive people - men and women both - had to hold fast to their cause. She characterized the matter as a "question of life or death."15

But considering Fairley's attention to the role of women in Canadian society only skims the surface of her career in developing the progressive cause. Her fulfillment of the cultural worker's responsibility to the people requires a much fuller analysis. But because there are few secondary references to Fairley's work, it is exceedingly difficult to estimate the complete scope of her activities, especially the non-literary ones. Scant published documentation between the demise of New Frontier in 1937

14 Margaret Fairley, "Nellie McClung," in New Frontiers (Summer 1956) 19-21; Tax, 459.

15 National Women's Committee, Communist Party of Canada, Canada's Women: At home, at work, children, equality, peace (Toronto 1963), 1-2. 
and the emergence in 1952 of another Marxist journal, New Frontiers, gives the illusion that this was a period of inactivity for her. However, during the early 1940s, she became involved in producing The Tribune, the Canadian Communist newspaper. At the time, Barker Fairley described The Tribune as "doing what it can to stem the tide of [wartime] propaganda." The six-page weekly printed "valuable correctives of the daily press, which," had become, he said, "less and less useful to any thinking person." As the war lengthened, the Canadian Communist movement was repressed, in large part by the Royal Canadian Mounted Police. The Party itself was forced underground and publication of The Tribune was suspended. ${ }^{16}$ The Labour Progressive Party (LPP), however, did emerge out of this crisis, and Fairley was one of its most prominent members. Thus, it is reasonable to assume that the national security measures of wartime stifled neither her energy nor her conviction.

A fortunate result of the disappearance of her literary outlets was the resumption of her work in the classroom. Lecturing for left-wing organizations such as the Toronto Writers Group and the Workers' Educational Association gave her ideas exposure to a suitably broad audience. To accompany her teaching, Fairley published in 1946 her first book, The Spirit of Canadian Democracy ${ }^{17}$ This spirit of democracy - the activism and expression of the people — was, she believed, the common thread in Canadian history. It most often appeared as the tendency to organize for struggle. The book's theme in large part mirrored particular struggles in Canadian and world politics during the 1930s. With the rise of fascism, the world witnessed "the strongest tide of reaction which [had] ever taken place." However, the democratic spirit existed amongst Spanish and Chinese revolutionaries, and also amongst the Canadians who supported the International Brigade. The Second World War was also an extension of the anti-fascist struggle. In victory (writing The Spirit in 1945) Fairley expressed the hope that the world would continue in the direction of progress. ${ }^{18}$

Clearly this "conscious democratic fellowship" had become more and more the trend in intellectual circles. But despite its image, democracy was not to be perceived as an elite concept; it was, in Fairley's opinion, much more characteristic of the masses. This basic understanding informs the entirety of her subsequent work. "Canadian history," she wrote, "has not just happened; it has been made year after year by the patient deeds of such men as those whose words fill this book [, by people]...fighting day by day with word and pen and hand raised in vote." Certainly, she included the words of elites like Gourlay, Mackenzie, Papineau, and Howe, but mainly she championed the largely unknown petitioners, voters at conferences, poster authors, and editorial writers whose words she excerpted in The Spirit. To her, the most "heroic" Canadians were "the men and women who write the truth, even when it is unacceptable to the authorities, and when it may get them into trouble. We have had many such writers in Canada," she wrote, "though most of them are little known, and few have established themselves in the world of literature." ${ }^{19}$ For this reason, her work from the mid-1940s until her death in 1968 consisted largely of explaining to

16 Fairley was responsible for the Trib's book page. Details about her involvement with this organ are drawn from letters from Barker Fairley to Christopher M. Grieve (8 February 1940, 4 September 1940, 25 February 1941), MacDiarmid Papers, Edinburgh.

17 The Toronto Board of Education banned the rigorously researched anthology because of its potentially "subversive" content.

18 Margaret Fairley, ed., The Spirit of Canadian Democracy (Toronto 1946), 10-11.

19 The Spirit, 12; Manuscript Collection, volume 1, file "Her Writing notes (4)," typescript "Heroic Canadian Writers," 1. 
Canadians why their own heroes were so unknown and what indeed was the great merit of their creations.

For a number of years in the late 1940s and early 1950s, Fairley gave a course on "Literature in English-Speaking Canada" for the Toronto Writers Group. ${ }^{20}$ Her first lecture introduced the historical background, and she encouraged her students to supplement their understanding of Canadian society by reading Stanley Ryerson's Birth of Canadian Democracy, Tim Buck's Canada, the Communist Viewpoint, and Carl Wittke's progressive survey text $A$ History of Canada. Plainly, she had no reservations about whatever political slant these authors may have had; their unorthodox ideas well suited her lessons. The first of these talks considered the character of pre-Confederation Canadian literature. She highlighted the work of Haliburton, Howe, and Mackenzie, as well as that of lesser known writers such as Alexander McLachlan and Henry Alexander. Her most important conclusion about this period involved the implications of "colonial status" and "later subservience to the USA" which prevailed during that period. These facts accounted "in some degree for Canada's failure to produce a great bourgeois literature. The ruling class separated from the people, looking abroad for cultural ties." In turn, later bourgeois critics would tend to "see literature as something apart from ordinary life." ${ }^{11}$ Mindful of the thoughts of Marx and Gorki ${ }^{22}$ she repeatedly noted the harmful implications of class stratification on Canadian literature written by ordinary people.

Another lecture, this one on the first half-century after Confederation, considered the ideas of Wilfrid Laurier, Edward Blake, Louis Riel, and Stephen Leacock. Nevertheless, Fairley reserved a prominent part of the lesson for Robert Service, and two of her personal favourites, Pauline Johnson and Archibald Lampman. She felt very strongly about Lampman because of his "most human work and his most radical ideas [which] have been played down by anthologists and critics." Along with Lampman, although very different, Johnson and Service "reflect the lives of ordinary people, and are discredited accordingly by orthodox critics." ${ }^{23}$ Of course Fairley viewed this as a great shame. She felt that writers such as Johnson were among Canada's greatest and most devoted citizens. Through her travel, Johnson came to know the land and the people, and because of her Native heritage felt a deep sense of "loss to a foreign interloper." That sentiment was something Fairley believed all Canadians could share. Ironically, however, the best writers were "cold-shouldered by the clique of poets and novelists who are more at home with the cosmopolitan writers of the United States and Britain than with the people of Canada." These "upholders of the status quo cannot face it," she wrote, "for how are they to deal with widespread exploitation, lying propaganda, and bribed false witnesses." ${ }^{24}$ She therefore implored her students not to take mainstream criticism seriously.

20 My sources for Fairley's lectures are varied and somewhat unorthodox. Some typescript notes can be found in her Manuscript Collection. Where notes are not available, I have derived her substantive commentary from other (usually published) remarks on the specific subject. The main outline of the "Course in Literature in English-Speaking Canada" is from Manuscript Collection, volume 1, file "With Our Own Hands (Suppl.)."

21 Manuscript Collection, volume 1, file "Lecture notes (Canadian Literature) (1)," [a student's (?) summary notes].

22 cf. Karl Marx: "The objectification of human existence means making man's senses human, as well as creating senses corresponding to the vast richness of human and natural life"; cf. Maxim Gorki: "The literature of the Soviet Union is developing well, but the real life is splendid and magnificent. Literature must attain to the level of real life. That is the point." (Emphasis added.)

23 Manuscript Collection, volume 1, file "Lecture Notes (Canadian Literature) (1)."

24 [Margaret Fairley], "Pauline Johnson," in New Frontiers (Summer 1954), 43-44. 
She felt it imperative to deal with unpublished authors as well. This conviction might have produced one of her most important contributions to the study of Canadian culture. Unfortunately, very little of her work in this area was itself published. She never completed the book she intended to call With Our Own Hands: Records of the Making of Canada by the Makers Themselves ${ }^{25}$ In her lectures, however, she included a section on the writings of these people. Although simply "a report on a piece of research only begun," Lecture IV, "Diaries and autobiographies of Canadian Farmers" was a good sampling of the concept. The notion to write the book derived from her search for lecture material on non-famous Canadians. She told her students

The idea came when I looked in vain in histories of the CPR for any account of the people who actually built the railway. Or perhaps...from...[farmer, journalist, historian and Marxist philosopher] J.F. White [who] used to lead study groups [and] wrote a regular column on farmers' problems for the labor press.... So I decided that, if possible, I would find first-hand stories told by the workers themselves of the physical making of Canada.... Canada is one of the few countries in the world where it might be possible to get such an entirely first-hand account of its making from virgin forest and plain and mountain....such a history would be truer than the usual history of promoters and financiers and swindlers. ${ }^{26}$

She proposed to teach Canadians about the extremely interesting and progressive people of their country's past. One of them was Thomas Macqueen, 'The Socialist Poet of Upper Canada' who flourished in the first half of the nineteenth century. Fairley detected the progressive spirit in Macqueen's ruminations, ideas which anticipated by fifty years the well-known thoughts of Mark Twain (specifically the connections between war and illiteracy, and colonialism and the Church). He also "advocated the use of King's College and Clergy Reserve revenues for the benefit of all the members of the community; distribution of Crown patronage on the basis of merit only; equal Parliamentary representation; and a national, improved system of education." ${ }^{27}$ Nevertheless, because of his socialistic tendencies and his low rank, Macqueen was forgotten until Fairley uncovered his writing. Surely the words themselves were important to her, but she felt that the more important lesson of Macqueen's life was that he and forward-looking individuals like him were always being marginalized. Much of her teaching energy was, therefore, channeled into convincing her students that they cannot allow reactionary forces to silence them as they had Macqueen.

In Fairley's opinion, settlers, workers, and other pioneers were the best role models for her students and readers. They were engaged in a constant struggle to survive, and in this way they created their own lives and their own country. In Marxian terms, the pioneers controlled the means of cultural production and this offered them an exciting sense of the future, a loyalty to it, and a responsibility for it. These factors generated a "love of country" which she interpreted as "a positive patriotism." She celebrated the hardy spirit and diligence of people like Joseph Abbott who not only "created" their own lives but were willing, regardless of the lower status accorded them, to venture forward as activists in the hope of conveying useful information on the building of Canada. She found this spirit "very rare in our day in capitalist

25 For the project, Fairley placed a notice in the LPP newspaper The Tribune (27 February 1950) seeking accounts of the building of roads, farms, railways, etc. described in the words of the "manual workers" themselves. See David Kimmel and Gregory S. Kealey, "With Our Own Hands: Margaret Fairley and the 'Real Makers' of Canada," in Labour/Le Travail (Spring 1993), forthcoming.

26 Manuscript Collection, volume 1, file "Workers' and Farmers' Letters etc. (Lecture Notes) (3)."

27 Margaret Fairley, "Socialist Poet of Upper Canada," New Frontiers (Spring 1955), 34-38. 
countries where it is most frequently contaminated with nationalism combined with hostility to some other country."28 The democratic spirit of progress, however, was an integral part of the Canadian national tradition, and Fairley exhorted those who would listen to her to realize this fact.

Fairley's method of summarizing Canadian literature was to divide the discipline into two categories. She defined the groupings as "Reactionary fiction" and "Progressive fiction." Literature that is part of the first category

discourages energy - accepts the status quo - acts as an opiate - misinterprets human hopes and desires - takes a low level of activity and thought as the norm idealizes the past - idealizes the peasant or the child or poverty - produces an easy torpor, or an easy optimism.

On the other hand, progressive fiction

which is the same as good fiction, stimulates energy, asks disturbing questions, poses problems, shows man in difficulties and leaves it to him to get out of them, shows the past as always conscious of itself as the present, spreads a knowledge of how people live, and what they dream, sheds no glamour over poverty or ignorance. ${ }^{29}$

Luckily, she said, Canadian novels were written more often by progressive members of the middle class, "people who see more or less clearly the evils of life under capitalism," for example Gabrielle Roy. ${ }^{30}$ But the pace of this bourgeois route was not quick enough for Fairley. She asked

What is needed to speed up the awareness of Canadian writers? A sense that they are important...for the enlightenment of their fellows. The Party could help here, to make workers realize that good fiction reaches large numbers of people, and that anyone with a gift for writing should be encouraged.... Hosts of people read novels who would never dream of reading a pamphlet or a political book. These people can be shaken from their complacency; they can be compelled to think; they can be stirred to feel; they can be energized to act; by novels. ${ }^{31}$

Her classroom instruction could reach only a limited audience, but her perspectives were nonetheless important and relevant. For example, the cultural commission of the Labor Progressive Party echoed her ideas about cultural activism. Fairley advised Party workers not simply to monitor highbrow culture but "to make a survey of the cultural life of Tom, Dick and Harry," a notion true to her own emphasis of the people's culture rather than elite culture. "It is the job of progressive people to use their influence on the cultural products that people already consume." She advised that

Careful studies of single radio programs, record, Penguin [paperbacks], museum pieces of pottery or clothing, could be the source of great cultural enrichment to many people who are now rather vaguely walking through the Art Gallery and Museum or

28 Margaret Fairley, "Roots of Canadian Patriotism in English-Speaking Canada Before Confederation," Marxist Quarterly (Winter 1963), 1-6, and "An Early Diary," in New Frontiers (Autumn 1954), 21-23.

29 Manuscript Collection, volume 1, file "Her Writing Notes (1)," typescript, "Some Notes" on Literature, with Special Reference to the Canadian Novel," 2 (emphasis added).

30 "Some Notes...;" also see Fairley's review essay "Gabrielle Roy's Novels," in New Frontiers (Spring 1956), 7-10. Fairley admired Roy's broad understanding of life and her sensitivity to human suffering. "She knows so much," Fairley wrote, "about the roots of suffering and joy, and has, at the back of her vision, a clue to the way ahead," 10.

31 "Some Notes...," 6. 
listening to the Proms [Promenade concerts].... Bourgeois critics are mostly devoid of any clear understanding, and without direction.

For both reasons, but especially the latter, concerted activism on the part of the LPP was necessary. Furthermore, as Fairley noted, "it would be a mistake to wait for an expressed demand; the demand is already here, and there is ample evidence of it in the life of the people." ${ }^{32}$ Conceivably, her remarkable ability to detect the subtleties of cultural production and consumption derived, more than anything else, from her keen and on-going sensitivity to the behaviour of the general public.

Certainly by the 1950 s, Fairley's ideas about cultural production were built solidly upon Marxist principles. To these she added an important new theme, the independence of Canada. National autonomy had long been an issue for Canadian leftists. Since the 1920s, social democrats and Communists alike gave emphasis to the dual fact that Canada was still part of the British Empire politically, militarily, and diplomatically, and that the U.S. exerted its influence on economic matters. For Marxists like Tim Buck, the details of which specific external power controlled Canada did not matter. "Capitalism is capitalism," he said. Moreover, "Independence...is [just] a step towards Americanization [for the] dominant economic interests." However, as Norman Penner notes, Buck's comment was "outside the Communist frame of reference. It did not refer to anything that Marx or Lenin said on the national question." Years later Buck restated in a more orthodox turn of phrase: mainstream demands for Canadian independence, he said, had always had merely bourgeois independence in mind. Although some Canadians, Maurice Spector for example, called for a Bolshevik revolution as the only means of gaining "real independence," it is noteworthy that classical Marxism only ever entered obliquely into CPC ideology. ${ }^{33}$

During the "conservative" 1930s and the war years, Marxists eschewed nationalism because of its perceived fascistic overtones. By the late 1940s, however, with the post-war world order taking shape, Canadian Communists revived the issue of national independence, this time infusing their arguments with more orthodox Marxist-Leninist thought. Party members were "convinced that the fight for national independence from U.S. domination was the key...to a socialist transformation of Canada." Encouraged by Stalin's exhortation to "Communist parties in capitalist countries to take up the "banner of national independence,"' the LPP devised its "Put Canada First" slogan and Canadian Independence and People's Democracy platform in 1952:

To achieve these high patriotic aims [sovereign Canadian control over our resources, industries, armed forces and foreign and domestic policies] Canadians must unite to defeat the numerically small but powerful clique of speculators and monopolists and their political representation who are perpetrating a national betrayal - to hurl us into a third world war for the U.S. trusts.

Furthermore, "U.S. penetration in the fields of culture and arts [calls for] the fullest promotion of Canada's own material forms of literature and art which express the democratic traditions of our people." Penner comments that, after 1947 and certainly

32 Manuscript Collection, vol. 1, "Her Writing Notes (4)," typescript, "The Cultural Life in Toronto."

33 Norman Penner, Canadian Left: A Critical Analysis, (Scarborough, Ontario 1977), 86-91. Ian Angus bitterly indicts the CPC's deviation from Bolshevism and class-struggle principles (for "an easier road") in the wake of the conservative 1930s in Canadian Bolshevik: The Early Years of Communist Party of Canada (Montreal 1981), 324. 
by 1952 , "Canadian independence from U.S. domination...became the all-pervasive theme of every aspect of Party interest." 34

The extent of Fairley's involvement in the development of the "Put Canada First" program is unknown. ${ }^{35}$ However, regardless of whether she was helping to forge the ideology or merely following it in her post-war activities, her work with New Frontiers and in later educational schemes are fine articulations of the postwar Canadian Communist program. ${ }^{36} \mathrm{Her}$ lectures on Canadian culture faithfully relied on Marxist tenets. For instance, she told her students of the implications of capitalism's development. It "pushed artists into their studios to paint canvasses for the wealthy [,]...in Canada it tended to build up the idea that literature was the concern of the leisured class.... The notion that life influenced literature was pushed into the background." And the extension of capitalism had another ill side-effect: "The result in Canada has been to ignore to a very great extent those authors and those writings which do not conform to a standard set of books rather than [to] life." She sensed that the public simply ignored the good work that was being done. For example, she said that

A characteristic of the decadent culture of our time is its neglect or scorn of ordinary, necessary work. Someone said that our fiction deals with life from eight p.m. on. This is true of films and plays and novels. But all writers who are even beginning to be progressive in their work cannot fail to deal with the working life of men. ${ }^{37}$

In her opinion, capitalist exploitation of culture, promoted in the mass media, accounted for this state of affairs. "Broadly speaking," she told her students in a lecture called "The Relation of Culture to Economic and Social Life,"

the makers of our culture are the money makers, the commercial interests exploiting culture for their own ends. How we think and feel, the houses we live in, the films we see, the books we read, the clothes we wear, the conditioning of our entire attitude, the radio programs we listen to, are all controlled insidiously and significantly by those who hold the purse strings. And if you go against these accepted attitudes, you are thought queer because this is not what is expected of individuals or artists.

But it was more than the media or peer pressure in society that made people unwilling to react. Drawing on her understanding of pedagogical methods, Fairley criticized "...the educational books on Canada which are prescribed by our schools." They give youngsters "the most extraordinary, completely idealistic picture of Canada as a sort of heavenly place, idyllic and Utopian." "Children reading and studying these kinds of educational books are conditioned early to go about with their eyes shut." It was no wonder to her, therefore, that general public resistance was so meagre. ${ }^{38}$

34 Penner, Canadian Left, 100-105, 109.

35 Penner was unable to comment on the extent to which Fairley was involved in central policy making. He, like most other writers about Communist parties, has little to say where Communist women are concerned.

36 Fairley was the founding editor of New Frontiers and moving spirit behind its operations. According to her premiere editorial, the journal aimed to "raise the sights of our people and...give them new confidence in their own power to bring about the fulfillment of their most urgent need: ...[peace and disarmament]." Canadian progressive culture, she continued, "cannot thrive if it is choked by a flood of cynical, degenerate products of US commercialism... New Frontiers will expose the danger to the Canadian people of the war-fostering US culture, while strengthening its tries with the democratic culture of the American people." (Winter 1952), 1.

37 Manuscript Collection, volume 1, file "Lecture Notes Can. Literature (2)," lecture transcript, "Canadian Literature 1867-1920."

38 Manuscript Collection, volume 1, file "Lecture Notes Can. Literature (2)," [W.E.A.?] lecture typescript, "The Relation of Culture to Economic and Social Life," (15 October 1947). 
Fairley was an ardent defender of the marginalized cultural worker. However, she was not so radical in her thinking that she called for a revolutionary overthrow of the dominant system in deference to the down-trodden proletariat. Rather she understood that Communist artists had to respond to and - for the present - work within the existing culture. Culture, she agreed, reflects the economic and social realities of a given place and time, and as both a product and producer of that culture, the Communist artist needs to understand a few basic principles: the cultural worker has to assess the status quo as a reflection of the life of the ruling class and the insecurity of the working-class; he or she must recognize the variety and diversity of cultural life and the desire of the ruling class to standardize it and to exploit it in advertising, amusements, etc.; the Communist artist must also, above all, be critical of bourgeois ideas - for instance, the false conception of individual freedom, the notion that science cannot be applied to human affairs, that success is measured by acquisition of goods, that women exist for the pleasure and service of men, and the bourgeoisie's anti-intellectualism and blind acceptance of white Christian prejudices. ${ }^{39}$

But Fairley thought it unwise to be entirely adversarial. For instance, she felt the progressive movement should accept any mainstream artist who exposes the insecurity of the ruling class. She was also willing to admit that there had been some positive achievements of bourgeois culture. She divided cultural achievements into two categories, "creative" and "possessive", and, to understand her work, it is important to comprehend the distinctions she drew. Possessive achievements include such things as libraries, museums, theatres, clubs, and orchestras; on the other hand, travel-books, landscape paintings, memoirs, etc. comprise the creative. All of these are among the positive bourgeois contributions. ${ }^{40}$

But there was an important contrast between the capitalist incarnations of these things and the socialist ones. Both creative and possessive aspects of culture are always present, regardless of the socio-economic environment. The difference is, however, that capitalism stresses the possessive and socialism the creative. "Creative culture under capitalism," Fairley noted, puts "great stress on the individual," star actors for example. It also promotes the "notion that art thrived on poverty, that art was a very special gift, that culture was for the select few, that it was extra, abnormal." Socialist creativity, on the other hand, stresses along with the wide opportunity for individual development "group work[, the] relation of work to popular needs and tastes[, the] belief that economic security helps the artist[, and the] belief that the great mass of people can participate in art." That would explain why possessive culture under socialism meets the demands of the people. In contrast, under capitalism, possessive culture is largely the domain of a "small select audience" and harbours a "contempt of ordinary people." ${ }^{11}$

But with respect to the Communist artist's attitude to these bourgeois achievements, Fairley felt that progress could be made by attempting to open wider the doors of existing cultural institutions. This could be accomplished in part by making trade unions and workers more aware of what possessive achievements were available. Of course, expressing a Marxist critique of cultural institutions and events was manda-

39 cf. the ideas of Karl Marx, "the first radical critic of cultural development," as discussed in Louis Dupre, Marx's Social Critique of Culture (New Haven, Connecticut 1983), 3-6, 13, 51-56, 258-259, 262-279.

40 Manuscript Collection, volume 2, file "(Notes); Culture, General Canadian," typescript notes, "Some questions and tentative answers on the relation of Communist artists to the culture of their country."

41 Manuscript Collection, volume 1, file "Lecture Notes (Canadian Literature) (1)," typescript [W.E.A.?] lecture, "The relation of culture to economic and social life - general," (Fall 1947)." 
tory in any attempt to remedy the situation. Furthermore, existing museums should be put to use as means of Marxist education (for instance in the scientific study of history) ${ }^{42}$ But Fairley had an important admonition to accompany her suggestions: Making use of bourgeois institutions for progressive ends was acceptable; but it was not safe or sufficient to rely on members of the bourgeoisie alone - not even those who had left-liberal tendencies. She gave as an example the "half-hearted struggle of men like [poet E.J.] Pratt against" the "theory of non-involvement." The struggle had to be fought assiduously by progressives on account of bourgeois tendencies to blind people to the "fact of reactionary propaganda[, and] to stem [the] enlightenment and activity of the people." Half-hearted efforts, Fairley said, "fostered defeatism." ${ }^{43}$ In sum, these thoughts comprised the conceptual basis of Fairley's analysis of the dynamics of Canadian culture.

The simultaneous emergence in the early 1950s of the Communist understanding and critique of Canadian culture (often articulated by Fairley on behalf of the LPP) and the state-sanctioned Massey Commission on National Development in the Arts, Letters, and Sciences is a fascinating coincidence. Both phenomena sought an understanding of the nature of Canadian culture in the post-war period, especially in terms of the ways Canada's independence and distinctiveness could be cultivated and accentuated in an environment of American penetration. Needless to say, Fairley's ideas differed enormously from the findings and suggestions of Vincent Massey. In short, the Commission was (in Fairley's opinion) blind to reality, and failed chiefly in three ways: it formalized the tired Canadian tendency of lamenting "what is not there"; its stand on defending Canadian culture resonated with militaristic overtones; ${ }^{44}$ and it ultimately failed to respond to the Americanization of cultural life in Canada.

Her response to the Massey Report, an article called "Our Cultural Heritage," was one of Fairley's finest essays. As an organ of the capitalist state, the Commission was, she wrote, predisposed to reactionary tendencies. In place of merely bemoaning the state of Canadian culture and describing in conclusion what was missing, Fairley asked "Why not examine more carefully what is there, find out its worth, and discover why, if such is the case, it has been hidden $?^{45}$ This had been her approach to Canadian culture since the early 1940s, but it did not surprise her in the least that it was not Massey's. In Fairley's estimation, Canada enjoyed (or had the potential to enjoy) one of the world's richest cultural heritages. Canadian history was a chronicle of constant struggle, and this produced "a culture which seeks to record, adorn and change the real life of men in our country.... Canadians have transformed their country with their own hard work.... We have had a tough experience, and have accomplished much with brain and muscle." She believed that Massey missed all this as a result of capitalism's dual effect of numbing the Canadian consciousness at the same time as it moulded minds for its own ends. Invoking again one of her favourite poets, she described the way in which Archibald Lampman had been silenced and excluded from general knowledge. He had written "several poems of vigourous protest against the looming war in South Africa, clearly tracing the connection between capitalist greed, war and the ugliness of life." But poetry like his was "too close to the life of

42 "Some questions and tentative answers..."

43 "The relation of culture to economic and social life - general."

44 According to Fairley's interpretation, "the [Massey] Report warns that in time of peace our cultural life must prepare for war; our military defences and our cultural defences "cannot be separated"," (Margaret Fairley, "Our Cultural Heritage," in New Frontiers (Winter 1952), 1.

45 "Our Cultural Heritage," 1. 
the working people to be accepted by conventional critics[, and] publishers preferred to boost the shallow work of romantic writers who had nothing to say." Even in the twentieth century, when writers had ample chance for exposing their ideas, the capitalist system drained the energy out of liberal-minded cultural workers. What, she asked rhetorically, had happened to the idealistic young poets of the 1930s Pratt for instance? Regardless there were poets who picked up the torch. Wilson MacDonald, for instance, "has been writing fierce poems of anger against the greed and lies and violence of the money-making civilization.... He has undoubtedly suffered neglect because of the pacifist and anti-capitalist content of his work." Fairley was not so naive that she questioned why MacDonald suffered the fate he did. She did, however, wonder why, if Canadians were truly looking for a distinct, legitimate cultural identity they chose to ignore expressions "of the real struggle of men for a living, for houses, for useful jobs, for education, for joyful life." She concluded that Canadian ignorance and lack of pride was a result of not just American but also capitalist control of Canadian culture. Her essay closes with a brief, ironic, and semi-imagined dialogue: A Soviet writer visiting in 1944 asked "why have you no great art depicting your great country?" Fairley wanted to reply "Who told you that? Some American? We have many who have recorded and adorned and tried to change our country. The trouble is we are ignorant of our heritage and uncertain as to our title to pride." 46

Several years after the Massey Commission suggested it, the Canadian government established the Canada Council. At this juncture, Fairley expressed her dismay that something as costly and elaborate as a royal commission was needed to "devise" something Canadians had been clamoring for years, specifically government support of the arts. Nonetheless, she welcomed the Council and hoped that it would be used as a tool for democratizing Canadian culture. But because the parent Massey Commission was so badly flawed, she worried about the Canada Council. "The danger is," she wrote,

that the Council has been used as a blind pretense, or as a body set up to control, instead of to stimulate, our cultural institutions. There can be no doubt that pressures from business and United States interests will be exhorted to check progressive initiative in the arts and education. If this is understood by enough people, counter pressures in the interests of the nation as a whole will prevail. ${ }^{47}$

Mixed optimism and caution was also her attitude toward the advent of television and the notion of private broadcasters. She realized that TV could be either "a vibrant national medium of entertainment, enlightenment and culture" or "a tool in the hands of advertisers." To that end, she tried to revive the popular debate that flourished in the 1930s about radio. She hoped there would be a similar outcry with similar results, specifically that the Canadian Broadcasting Corporation would take full control in opposition to American commercialism. The new medium could not be trusted to private hands. For example, the planned package of All-Canada Television consisted predominantly of "U.S. films and other crime and pro-war productions." Canadian viewers did not need any of this. Certainly, a truly all-Canadian network would be costly and make little practical sense. The development of east-west technology was, by any standard, illogically expensive in economic terms. But as far as Fairley was concerned, it made perfect sense in terms of Canadian politics and Canadian culture.

46 "Our Cultural Heritage," 2, 5-7.

47 [Margaret Fairley], "The Canada Council," New Frontiers, (Winter 1954), 2. 
"By taking this bold and progressive step we have expressed our willingness to pay a price for our national integrity." There were other reasons besides: a public television network would be source of employment for hundreds if not thousands of Canadian workers; like CBC Radio, TV could become a medium for the spread of knowledge of music, literature, drama, and Canadian and world affairs; furthermore, she argued that Canada needed television different in content and different in kind. Lastly, "Canadian enjoyment of first-rate Canadian talent is unquestioned." 48

However, Fairley's championing of Canadian television had a deeper root than this. It was part and parcel of the Communist policies against Americanization and in support of state-sponsored production of culture. She herself had witnessed the latter in practice during two visits to the Communist bloc in the 1950s. In the summer of 1954, she led a delegation of Canadians to Hungary, Poland, and Romania, "to learn something about cultural life in the People's Democracies." She interpreted the renewed joy, happiness, and high spirits she saw in these countries as a result of the people's natural, intimate enjoyment of and activity in culture, a sure benefit of their progress towards socialism. One wonders now whether or not what she saw in Eastern Europe and China (in 1959) reflected accurately the state of affairs in these countries, whether she saw only what her hosts wanted her to see, or whether her devotion to Marxism blinded her to or obscured her view of the social realities. Her vision was not so narrow that she attributed all the success she witnessed to socialism. However, what she did see confirmed her faith in the Communist system. The Poles, for instance, were working unsparingly to preserve and restore their traditional culture. "How lovingly and reverently the past is cherished" there, she wrote, implying the contrast to Canada. Perhaps the "knowledge of the past [which] is being built into the character of socialist men and women" and lacking in Canadians made the difference. ${ }^{49}$

In China, too, she noted that the current Cultural Revolution ${ }^{50}$ meant "the Chinese people are taking the culture of their country into their own hands." At the same time, the state was promoting pride in the pre-Communist Chinese cultural heritage as well as encouraging the people to take an active part in forging the culture of the present. There were, as far as Fairley was concerned, important lessons for Canadians to learn:

writers and artists who put self-expression first, despising the people at large and looking to one another for appreciation...have no place in a society which is remaking itself towards socialism.

However, in a socialist society like China,

The writer who is gaining ground in this most difficult revolution is beginning to understand that there need be no conflict between himself as a highly qualified individual and the collective of which he is a member. The richer his personality, the richer will be the collective, and the more encouragement will there be for other rich personalities to develop. Instead of living in isolation on the hill-top, he joins the hurly-burly below, enriching it with his deepening understanding of activity, joy and sorrow, and himself enriched by the realities of the struggle going on around him. ${ }^{51}$

48 [Margaret Fairley], "The Hucksters versus the CBC," New Frontiers, (Spring 1956), 1-4.

49 Margaret Fairley, "The Living Heritage in Eastern Europe," in New Frontiers (Winter 1954), 26; Margaret Fairley, "Thou Shalt Not Steal," New Frontiers (Fall 1955), 39.

50 Fairley used "Cultural Revolution" to denote what has come to be known as "the Great Leap Forward," and not Mao's final cultural policy (1966-1976).

51 Margaret Fairley, "Visiting Canadians Witness Cultural Revolution in China," in The Canadian Tribune (28 September 1959), 5, and "Cultural Revolution in China," typescript, Manuscript Collection, volume 1, file "Her Writing Notes (3)." cf. Karl Marx (The German Ideology): "The exclusive 
Whatever cultural activity Fairley saw in the 'People's Democracies' she understood as part of an organic socialist scheme. "Progress towards socialism," she wrote, is full and rich, and in it love of the past and present and future are closely connected. "It's all one process." If this scheme could be reduced to a simple set of formulas, Fairley's ideal would equate progressive activism and socialism with patriotism and pacifism. Another formula would equate respect for work with respect for people and with an understanding of life's continuities. It was these parallels that were helping to form the new socialist cultures of China and Eastern Europe. ${ }^{52}$ They could, according to Fairley, also accomplish for Canada the basic desiderata of radical patriots such as herself as well as those of Vincent Massey and his fellow patricians. Of course, she would call into question the motivations of the latter's designs.

She believed that the Canadian mainstream (Massey was just one exemplar) had fallen under the spell of an American cultural hegemony. Particularly disturbing proof was the fact that Canadians had come to subscribe to an American distillation of Canadian culture. ${ }^{53}$ Tim Buck also detected this trend and attributed it to the deleterious effects of popular culture. Even the working class was, in his view, becoming indoctrinated to a dangerous extent under the influence of the American capitalist ideology. ${ }^{54}$ For Fairley, there was no better example of this hegemony than an incident that took place in 1952. For whatever reason, six members of the Toronto Symphony Orchestra (TSO) were denied visas to travel in the United States. Soon thereafter, because their left-wing political sympathies had been revealed, these musicians were fired by the TSO. Fairley regarded this as a pro-U.S. conspiracy in the Canadian arts establishment. She expressed what seemed obvious to her, that "forces bent on bringing the art of our country into line with the policies of Washington" and against "the healthy determination of Canadians to think and act for themselves" were at play. The conspirators as far as she knew were U.S. State Department and immigration officials, Lester Pearson and the Canadian department of External Affairs, the TSO's Board of Directors, and the musicians' union bosses who did not come to the aid of the TSO six. This episode appeared to her to signal the threat of thought control:

The conspirators care little for the welfare of Canadian music and orchestras. They hear only the voice of the White House and the Pentagon. The attack...is a direct challenge to the self-respecting independence of.our cultural organizations.... It is a direct attempt to strangle resistance to the war policies of the U.S. Government.

However, the ever-optimistic Fairley highlighted the encouraging signs of the increasing opposition to what had transpired: the public was withdrawing its support for the TSO; some of the directors resigned; a petition was gathered together; several supportive editorials and letters of protest were published in newspapers. These were encouraging signs for her, pre-conditions of the Communist movement culture that Raymond Williams terms "counter-hegemony." 55

concentration of artistic talent in particular individuals is a consequence of the division of labor," etc. 52 "The Living Heritage," 26.

53 For example, see Fairley's review of $O$ Canada: An American's Notes on Canadian Culture, by Edmund Wilson, in Marxist Quarterly (Summer 1966), 90.

54 William Beeching and Phyllis Clarke, eds., Yours in the Struggle: Reminiscences of Tim Buck (Toronto 1977), 366-367.

55 [Margaret Fairley], "The Toronto Symphony Orchestra Six," in New Frontiers (Fall 1952), i. In 1949, Fairley was removed and permanently excluded from the United States because of her membership in the LPP. See Williams, Marxism and Literature (New York 1977). 
Fairley had, in a sense, advocated a Communist "counter-hegemony" throughout her Marxist career. To be counter-hegemonic was to be anti-American and therefore patriotic to Canada, and to accomplish this Canadians did not have far to look. Part of the problem was, as Fairley told her Canadian literature class, that

People who say there is no Canadian culture are looking for the same kind of culture here as they have in other countries. This is a mistake. This country should be looked upon as a different kind of country. Our kind of country could not produce the same kind of things that England or any other country has produced, so there is no good looking for them here. ${ }^{56}$

Later she wrote for the fifth anniversary program of the International Co-operative Cultural Group

We are Canadians. All that we think and do has Canadian soil beneath it, a Canadian climate around it, a Canadian past behind it, and a wonderful Canadian future ahead. This is a simple fact, not something to argue about. But it is a fact which people forget when they would like us to bury our natural thoughts and feelings and accept as our ways the ways of those forces in the United States who are corrupting, not only their own people, but also many in the countries which they seek to dominate.

The people's counter-hegemony was, in her opinion, the most effective way of settling Canada's cultural identity and of establishing national independence. It was also, as Fairley argued throughout her career, plain to see if Canadians only looked for it. "It is the Labor of Canadians which is creating our nation, and it is our labor which is the basis of our culture." To strengthen Canadian sovereignty, one merely had to take part: "Every evening spent [enjoying Canadian culture]" was, in her opinion, "a blow to the bomb-culture of the United States" and imperialist American designs. ${ }^{57}$

Fairley once posed-two questions which fittingly encapsulate her position on Canadian culture. First, she asked "Is the root of our struggle against Yankee domination of our culture?" In other words, is working against the penetration of American ideas a significant part of the Canadian cultural backdrop? One might not expect her to have made such a reduction. However, she did comment that

So long as monopoly-controlled entertainers despise their audience as they do today, so long as the intellectuals play along with monopoly in claiming an elite audience which despises the simple experiences of life as subject matter for art, so long shall we have this struggle on our hands.

Yes, for the time being, it would be an important component of Canadian culture. It would at least be the case as long as Canadians did not realize the potential to be self-sufficient in the production and consumption of their own culture. This begs the second of her questions: "How much of our heritage is available now?" The answer she gave was "A great deal, and it would be a mistake to underestimate what has been done through research and organization. ${ }^{" 58}$ Ironically, a lot of that work had been done by Fairley herself. If, however, she and others doing similar work could convince Canadians that their cultural past was rich and worthy of pride and attention,

56 Manuscript Collection, volume 1, file "Lecture Notes Can, Literature (2)," typescript [W.E.A.?] lecture "Canadian Travel," [Fall 1947?].

57 Margaret Fairley, "Create and Cherish Canadian Culture" (opening message to the Fifth Anniversary Program of the International Co-operative Cultural Group, Port Arthur, Ontario, (May 1954), in Manuscript Collection, volume 1, file "Her Writing Notes (4)."

58 Manuscript Collection, volume 1, file "Her Writing Notes (1)," typescript [speech?], "Our Cultural Heritage," [Fall 1955]. 
that would only be half the battle. In some way, Canadians would also have to overcome both the persuasive forces of the North American cultural hegemony and the false consciousness that made large numbers of Canadians ignorant and complacent.

In her last article (published posthumously), Fairley instructed a new generation of cultural workers on how best to go about accomplishing the aims she had striven for over the years. The cultural worker's role was "to enlarge the experience of the people, giving them through thought and feeling a widening and deepening of their whole personalities." This work would awaken citizens to the struggles of everyday life. But to make their work all the more effective,

Our first responsibility is to understand these struggles as they affect our next-door neighbors. Our second is to express these struggles in our own work. Our third is to help young people to break away from the empty, non-committal attitudes which are fashionable.

Fairley's career ended at the height of the Cold War. This historical coincidence clarifies why Fairley worked so diligently to promote Canadian national autonomy, cultural awareness and self-sufficiency, as well as class and gender equality. She felt that human dignity, a high standard of living, and not having to worry about the destruction and turmoil of war would be more difficult to achieve if Canadians were denied their right to a national consciousness..$^{60}$ Fairley was one of many remarkable Canadian Communists who became strongly engaged in peace activism despite the McCarthyite Zeitgeist. Lawrence S. Wittner, studying the contrasting American case, describes how an apparently aggressive Communist bloc in post-World War Two Europe caused many defections from the ranks of American radical pacifists. Responding in large part to fear-mongering anti-Soviet propaganda in the U.S. media, in 1948, the American Communist Party itself (CPUSA) "scrapped Marx and rushed to install [liberal] Henry Wallace as its patron saint." Wallace had accused CPUSA of "defend[ing] everything Moscow does." Nevertheless, many American Marxists turned to him because they understood his vision as the only real alternative to war. ${ }^{61}$ It seems that almost from the moment Nazi Germany fell, North American newspapers and other forms of popular culture had turned up the volume of alarm. The 'Free World' now had to defend itself against a new aggressor: Communism.

But such propaganda neither influenced Fairley nor caused her faith in Marxism to waver. Neither did Khrushchev's 1956 'revelations' about Stalin's reign of terror. Rather, she continued to exemplify postwar Canadian Communists who retained, despite a mass exodus from Party ranks, what Merrily Weisbord calls "a profound humanism." ${ }^{62}$ Fairley's humanism and her determination to stay within the Communist fold led to her leadership in the CPC's accelerated efforts in peace activism once Cold War tensions overshadowed (in the eyes of Party members) both Stalin's atrocities and Soviet imperialism. By the early 1960s, the CPC was also becoming

59 Margaret Fairley, "The Cultural Worker's Responsibility to the People" in Marxist Quarterly (Spring 1968), 4-6.

60 Barbara Roberts cites Linda Schott's thesis on the imperatives of maternal pacifism, much of which echoes the priorities of Margaret Fairley, (see Roberts, "Women's Peace Activism in Canada," in Linda Kealey and Joan Sangster, eds., Beyond the Vote: Canadian Women and Politics (Toronto 1989), 276-308).

61 Lawrence S. Wittner, Rebels Against War: The American Peace Movement, 1941-1960 (New York 1969), 187-192.

62 Merrily Weisbord, The Strangest Dream: Canadian Communists, the Spy Trials, and the Cold War (Toronto 1983), 229. 
mindful of the fact that peace activism was an increasingly popular cause amongst many young adults. To seize this opportunity, the Party published a booklet, Highways to Peace: A Challenge to Youth, under Fairley's editorship. Her editorial pages explained that "First of all we are missing security. We do not know whether life or death is in store for us and our families." A large part of her argument was cast in rhetorical questions: "Would you not give a great gasp of relief if you were to hear on the news tonight that disarmament was agreed upon? What would this mean to you?" "Would there not be, especially among young people, a great upsurgence [sic] of hope and ambition? And would there not be at the same time an opening of opportunities?" Her last point was the most typical and salient comment: "We need the chance of a maximum education for everyone so that no energy be wasted, no talent underdeveloped." Her common-touch style and precise argument made the message easy to understand. And she concluded with one more simple question: "Is it common sense," she wrote, "to make no protest when our governments spend billions on war preparations while they haggle and delay about expenditure for education, housing, health and medical research?"63 Fairley, although approaching her eighties, showed in this pamphlet that she was still on the leading edge of both the international Communist and peace movements. But her interests and activities never had been esoteric. Throughout her long career, her definition of peace consistently addressed structural issues such as social justice, and class, gender and racial equality. ${ }^{64}$

Obviously, Fairley would not witness global disarmament or world peace in her lifetime. However, typical of the way she regarded life and of her concern for fellow citizens, it is fitting that some modicum of serenity in her own neighbourhood was achieved through her efforts. One of her last projects involved the creation of a park in the overcrowded Spadina precinct of Toronto. She was among the first to recognize the benefits for children and the elderly of some green-space in the congested residential area. Appropriately, on 10 October 1972, a park at the corner of Brunswick and Ulster Streets was dedicated in her honour.

However, a much more suitable memorial to Fairley would have been a wider recognition of her work, particularly in the field of Canadian culture. At the time of her death in 1968, Stanley Ryerson wrote in tribute that she "held a special and honored place not only in the Canadian left but in the wider community" as well. The journals she founded and fashioned Canadian Forum, New Frontier, The Canadian Tribune, New Frontiers, Marxist Quarterly "played a part in helping to define and clarify the perspective of Left-moving artists and intellectuals in terms of Canadian and world issues." However, Fairley herself admitted that "our own progressive periodicals...reach only the limited number who for the most part are already on the right track." ${ }^{65}$ Yet, plain to see are the links between Fairley and those intellectuals and artists who did receive her ideas and in turn propagated them, through their own work, to the general public.

Of course, her ideas were flawed in many ways. Post-Communist readers would detect the most obvious - Fairley's purblind championship of the post-war "People's

63 [Margaret Fairley, ed.], Highways to Peace: A Challenge to Youth, [Toronto, 1961?], 16-17.

64 cf. the position of the non-partisan peace group Voice of Women, in Roberts, 298. Another interesting comparison is the British case, (see Richard Taylor, "The Marxist Left and the Peace Movement in Britain since 1945" in Richard Taylor and Nigel Young, eds., Campaigns for Peace: British Peace Movements in the Twentieth Century (Manchester 1987),162-188).

65 [Stanley Ryerson (as editor)], in Horizons, (Spring 1968), 1-2; [W.E.A.?] lecture, "The Relation of Culture...," [15 October 1947], 2. 
Democracies" as models of progress through socialism in action. However, she at no time considered Stalin a hero. He was simply the Kremlin's figurehead; by the same token, Stalin never said very much to influence Fairley as a Communist cultural worker. Furthermore, she was by no means alone in remaining a member of the Party in the wake of Khrushchev's revelations. The anti-American tone her cultural nationalism acquired was equaliy defective. Ironically, she had always condemned the "patriotism" that became "contaminated...hostility to some other country." ${ }^{66}$ But in this case she was merely charactuizing America as a bogey, a symbol of capitalist imperialism. Certainly she embraced the fundamental American notion of democracy and felt a deep sense of comraceship with the "people" of the United States. But her own notion of cultural nationalism was never chauvinistic or jingoistic like the ideas she perceived emanating from south of the border.

Nor was it elitist like that embraced by Vincent Massey and his confederates. Her theories were different because they were informed by what could be labeled "proletarian humanism." Fairley was a consummate supporter and defender of the common person and of what Maxim Gorki called "real life." She adhered strictly to Marx's social critique of culture: in a humanized world, where nature and human activity were re-integrated, an aesthetic awareness capable of unifying all other forms of consciousness would develop. Canadians needed to summon up national memories of resistance and achievement. To cure the twin "virus" of self-deprecation and the subservience mentality, she felt Canadians had to expose their character and build on the best aspects. In the future as in the past, "the assertion of a genuine, democratic national spirit [is] left to the working people," she argued. Associated with this humanism was Fairley's admonition that young artists and audiences must be helped "to look upon the world, and understand and admit that what they see going on around them is far more important than what is going on, or failing to go on, in their own heads. ${ }^{.67}$ Lastly, her way of dealing with her critics was itself deeply humanistic. The best example of this was expressed as a critique of a United Church of Canada report on "Communist Faith and Christian Faith." Maybe this article was her ultimate reconciliation with the Christian father whose world-view she had long ago rejected:

It seems to me that a head-on confrontation of my views with yours is seldom fruitful. What is fruitful is a discussion about ideas, affairs and actions looked at by you and me together.... If our minds are set on the future of mankind, our thinking, whether we are Christians or Communists, will become dynamic and creative, and we may be surprised at the degree of unity which we will achieve. ${ }^{68}$

The work for which Fairley is most widely remembered is her book Selected Writings of William Lyon Mackenzie 1824-1837, published in 1961. This is a remarkable volume in many ways, but one particular facet is most impressive: even in a collection of one man's work, Fairley was able to emphasize the "democratic" spirit of Mackenzie's ideas. And, as her descriptions show, both historian and historical subject shared many characteristics: Both kept their minds "fixed on the needs and grievances of [their] countrymen, and did not allow [themselves] to be diverted for long into personal disputes." Both had "an immense respect for factual evidence." Both "rightly saw the Reform movement in...Canada as part of a long and widespread process, and [were] at pains to remind [their] readers of similar move-

66 "Roots of Patriotism...," 6.

67 "Canada Day 1954," 1-2. "The Cultural Worker's Responsibility...," 5.

68 Margaret Fairley, a critique of "Communist Faith and Christian Faith," in Marxist Quarterly (Spring 1966), 29-30. 
ments in different parts of the world." They each "knew the Canadas of [their] day at first hand,..." and neither "seldom makes us aware that he[/she] is a newcomer...." As well, they "never failed to put education high up on [their] list of needed reforms, and repeatedly emphasized the need for an informed electorate and an entirely literate population." ${ }^{99}$ The likeness is significant.

On other occasions, Fairley composed words that could aptly describe her own life. Writing about the South African socialist-feminist novelist Olive Schreiner in 1929, she concluded:

Her views were never doctrinaire, but always deeply rooted in her first-hand knowledge of life. She was not interested in those purely political questions which do not directly touch human nature; but where the lives of men and women were at stake, she threw the whole force of her personality against greed, falsehood, injustice, oppression, and violence. In any important issue she went straight to the unequivocal facts, and based her opinions upon them. In her discussion of the position of women in the world, for example, [her] argument is solid and unassailable compared with that of most platform orators on the subject. So, too, in religion; her freedom of thought is not the usual vague, negative products of doubt and materialism; it is a vitally real and spontaneous energy of spirit, breaking through the old bonds, and rising on wings to explore new heights. ${ }^{70}$

With the very same phrases, Fairley might have concluded her own autobiography.

This introductory essay has considered much of Margaret Fairley's intellectual corpus. But it is, in many respects, no more than a cursory first glance. One hopes, however, it will accomplish several goals: first, to inform historians of left politics, of women's experience, of the peace movement, and of ideas and cultural matters that her legacy exists in a physical sense to this day, in a manuscript collection and now-obscure journals, remote though it all may seem; second, to posit before the same scholars the notion that Fairley's ideas and her activism had some enduring influence on the shape of Canadian culture and the way in which it is perceived; and third, to suggest that knowing the life of this particular Canadian helps to bridge many of the gaps in the historiography of culture, women, peace, and the left. This introduction is only just that - a beginning; but it is also a challenge to historians and others with something to say about the teaching of Canadian arts and letters to discover and include Margaret Fairley and, more importantly, people like her in their own scholarly endeavours.

69 Margaret Fairley, ed., Selected Writings of William Lyon Mackenzie 1824-1837, (Toronto 1961), $11-13,15,16,67,68$

70 Margaret Fairley, "The Novels of Olive Schreiner," Dalhousie Review (July 1929), 179-180. 